\title{
Evaluation of RES-E support policies in the Baltic States
}

\author{
Dagnija Blumberga $^{\mathrm{a}}$, Aiga Barisa ${ }^{\mathrm{a}}$, Ivars Veidenbergs ${ }^{\mathrm{a}}$, Andra Blumberga ${ }^{\mathrm{a}}$, \\ Reeli Kuhi-Thalfeldt ${ }^{\mathrm{b}}$ \\ ${ }^{a}$ Riga Technical University, Kronvalda Boulevard 1, Riga, LV 1010, Latvia \\ ${ }^{b}$ Tallinn University of Technology, Ehitajate tee 5, 19086 Tallinn, Estonia
}

\begin{abstract}
Electricity generation is a key sector to consider in a policy aimed at mitigation of greenhouse gases. Renewable energy sources can create substantial environmental and socio-economic benefits such as minimizing greenhouse gas emissions, improving energy security and promoting local economy. A wide range of policy measures are available for national governments to promote renewable electricity generation. Despite the positive effects of increased renewable energy share in national energy balance, it is often associated with high implementation costs. Given the importance of promoting renewable power deployment, and the high financial costs associated with support, it is essential for governments to be aware of performance and effects of introduced or planned policies. An evaluation can help to identify potential adaptations and allocate financial resources as efficiently as possible. This article evaluates policies in support of the deployment of renewable power generation. Power sectors of the three Baltic States - Lithuania, Latvia, and Estonia - are investigated. The aim of the study is to evaluate the existing policy measures and propose new solutions for further renewable electricity support. Analysis is based on system dynamics modeling approach. This modeling approach has been chosen due to its flexibility for extension and revision to address additional questions as they arise. Results suggest that electricity feed-in tariffs are effective in terms of installed capacity increase. However, the intensity of support for each source of renewable energy should be reasonably determined in order to contribute to achievement of national renewable electricity targets.
\end{abstract}

Keywords: energy efficiency; electricity; feed-in tariff; subsidies.

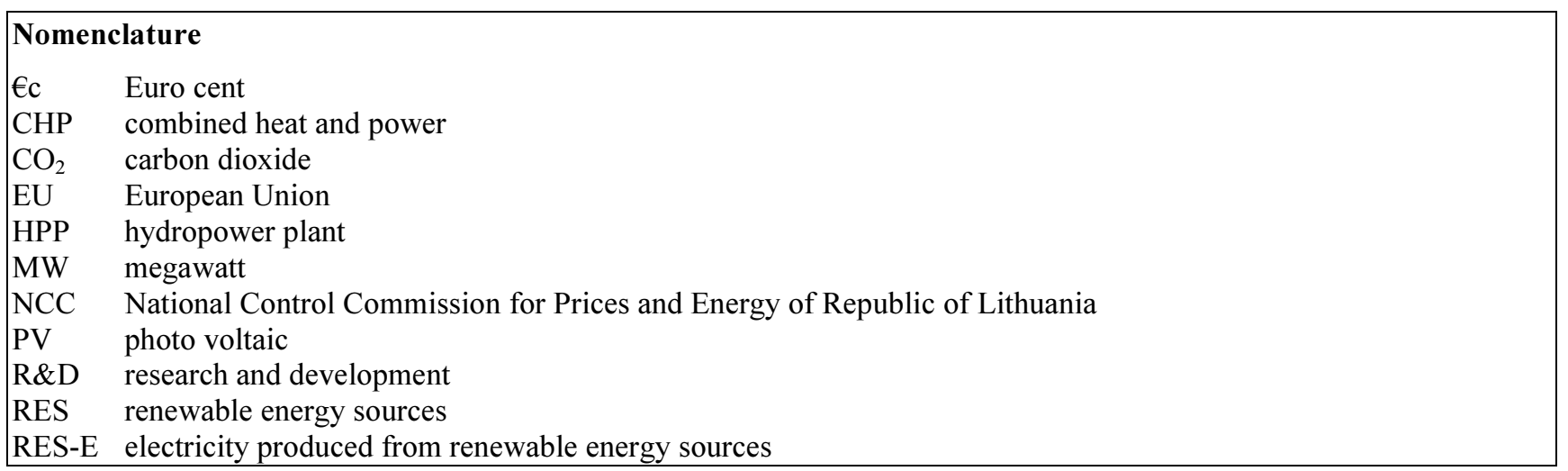

\section{Introduction}

To combat climate change, the European Union (EU) has agreed on two ambitious targets for 2020: 1) to reduce greenhouse gas emissions by $20 \%$ compared to 1990 levels and 2) to increase the share of renewable energy sources in total energy consumption to $20 \%$ [1]. Verbruggen and Lauber [2] stress that in a sustainable energy future, electricity is going to play a role of increasing importance and that the transition of the present non-sustainable energy systems to systems with renewable energy as the standard will take place first and fully in the electricity sector.

Corresponding author: Aiga Barisa. E-mail address: aiga.barisa@rtu.lv

http://dx.doi.org/10.3846/enviro.2014.255

(C) 2014 The Authors. Published by VGTU Press. This is an open-access article distributed under the terms of the Creative Commons Attribution License, which permits unrestricted use, distribution, and reproduction in any medium, provided the original author and source are credited. 
The cost of electricity produced is the major factor based on which the technology choice for electricity generation is done [3]. Electricity generation from renewable energy sources is still more expensive than conventional fossil fuel technologies. However, such factors as the rapidly growing market for energy, the technological progress and potentially increasing fossil fuel prices over time point to increasing competitiveness of renewable energy technologies compared to fossil-fuel-based power plants [3]. Meanwhile national governments are applying a number of support policies to initiate the development of alternative markets for electricity generation.

\subsection{Classification of renewable electricity support policies}

Governments are implementing various carbon reduction and renewable energy policies to improve the sustainability of the electricity sector. Renewable electricity policy mechanisms generally can be categorized into price-based and quantitybased policies [4]. In price-based instruments, the regulator sets a price for a specific variable. E.g., generators of renewable energy receive financial support in terms of a subsidy per kilowatt of capacity installed, a payment per kilowatt hour produced and sold or a fixed premium above the electricity market price [5]. Both capacity and generation supplies can be qualified by renewable energy source, by technology, by ownership, and any other attributes upon which the terms of support can be applied and that are in some way measurable [2]. In quantity-based policies, the desired level of outcome is set and an artificial market is created in which participants act to fulfil the policy target. In such way price for the regulated variable is determined by the market [4]. These systems operates under the principle that a defined member of the electricity supply chain (consumer, generator or supplier) has to present a fixed minimum quantity of certificates originated per megawatt hour of renewable electricity generated [6].

Support expenditures are usually charged to public budgets [2] and are paid by all electricity consumers corresponding to their consumption level. Thus the increasing expenditure on renewable energy has become a source of concern for governments all over the world [7]. This was one of the reasons that contributed to the discontinuation of feed-in tariffs in Latvia till 2016.

Feed-in tariffs are among major instruments used by public authorities to support renewable electricity supplies in their infant stages [2] and are the most popular RES-E support scheme in the European countries [8]. A feed-in tariff may be structured as either a fixed-price tariff thus guaranteeing electricity operators a set price for electricity sold to the grid, or a premium tariff, which adds a definite bonus to the wholesale market price perceived by generators. The duration, over which the tariff is paid, as well the tariff amount varies between policies applied in countries. In order to control the enrollment of RES-E generation, some countries cap the total capacity that can be installed or total tariffs that may be awarded under the scheme each year. Some countries have introduced a mechanism to gradually reduce the tariff rate thus adapting to increasing economic viability of RES-E technologies over time [8].

Other types of RES-E support policies include: tradable certificates, tax incentives and investment grants, net-metering policies, and tendering schemes all of which are applied in European countries separately and in combination with other policy incentives. However, Fouquet [6] concludes that so far, well-designed feed-in tariff systems for renewable energies with guaranteed access to the grid have proven the strongest reliability and success.

\subsection{Context of renewable electricity support policies in the Baltic States}

\subsection{Latvia}

High dependency on imported fossil fuel resources is seen as the main drawback of Latvian energy sector. In 2012, gross electricity consumption in Latvia was $6,848 \mathrm{GWh}$ [9] which was a $10.6 \%$ increase compared to previous year and $19.5 \%$ increase compared to 2005 level. Electricity generation amounted to 6,168 GWh, from which 3,707 GWh were produced in hydropower plants and $407 \mathrm{GWh}$ in other RES-E facilities; the rest coming from natural gas $(2,347 \mathrm{GWh})$ [10]. In 2012, electricity imports amounted to 4,935 GWh and electricity exports - 3,244 GWh [9].

The share of renewable energy sources of gross national electricity consumption has been inconsistent over the past years: $41.2 \%$ in $2008,49.2 \%$ in $2009,48.5 \%$ in 2010 and $41.9 \%$ in 2011 . In Figure 1 the development of RES-E generation and installed capacity in Latvia up to 2012 is illustrated.

Besides hydropower, wind power, biomass and biogas contribute to electricity generation from renewable energy sources in Latvia. As illustrated in Figure 1 wind energy has shown the most noticeable breakthrough over the past decade reaching $60 \mathrm{MW}$ installed capacity in 2012; it is followed by $43 \mathrm{MW}$ installed biogas capacity and 23 MW installed biomass capacity. It is expected [11] to increase the share of renewable energy sources to $59.8 \%$ of gross electricity consumption by 2020. Further the Latvian Energy Long Term Strategy 2030 (2012) [12] sets a target of a 50\% share of energy from renewable energy sources in gross final energy consumption by 2030 . This means $15 \%$ increase compared to 2011 level $(35.2 \%)$ which will not be achievable without appropriate policy incentives. 


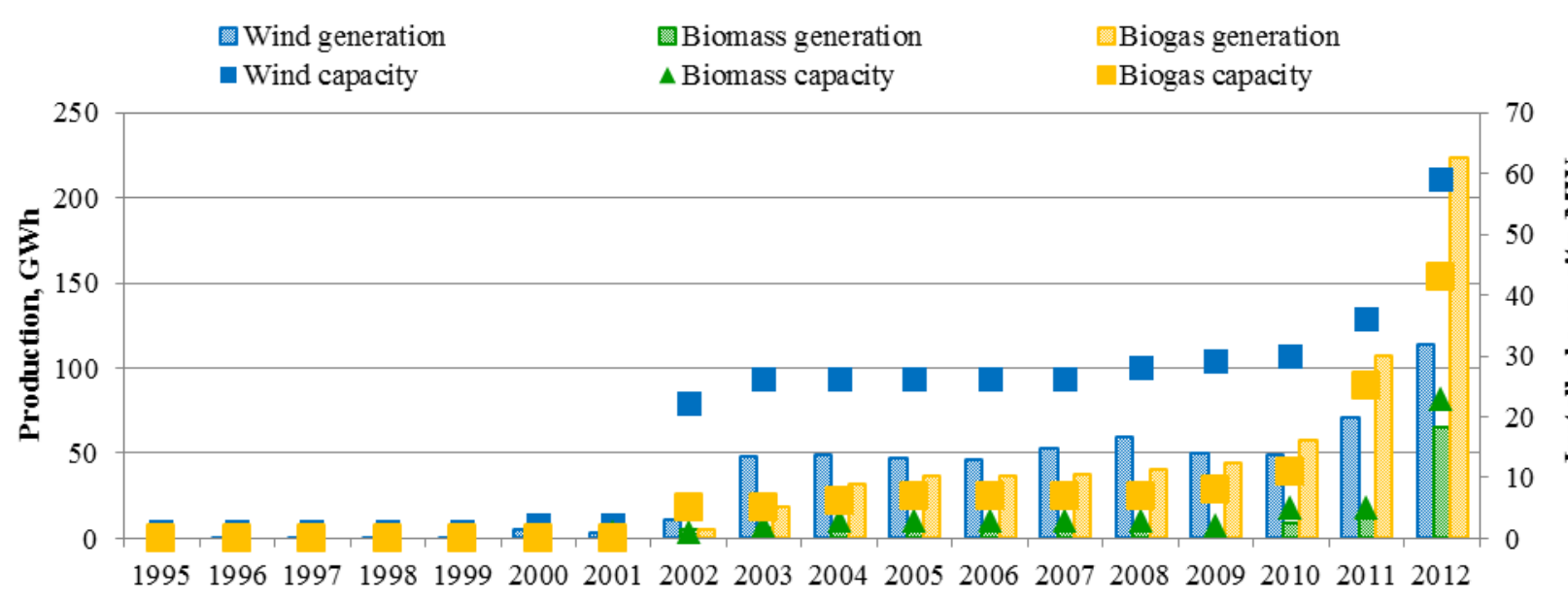

Fig. 1. Renewable electricity in Latvia (except hydropower) (Data source: [9])

In Latvia, power generation from renewable energy sources is promoted through a complex support system based on a feed-in tariff, which also includes elements of a quota system and tenders. All renewable energy technologies (except hydro power $>10 \mathrm{MW}$ ) are eligible for support. The tariff rates for electricity from renewable sources are calculated based on the price of natural gas and applying a certain coefficient depending on the plant size. Different regulation applies to electric and combined heat and power (CHP) plants. Feed-in tariffs are paid for a period of 20 years and rights for selling electricity within the mandatory procurement are granted in a tender procedure. A reduced feed-in tariff rate is stipulated for the operators of renewable electricity plants after the first ten-year period from the commencement of operation.

Average feed-in tariff rates paid for operators in 2012 are presented in Table 1. From Table 1 can be seen that support for electricity producers in 2012 was in range from 10.7 and $11.1 € \mathrm{c} / \mathrm{kWh}$ (wind power plants and large CHPs) to 18.5 and $19.5 € \mathrm{c} / \mathrm{kWh}$ for biomass and biogas power plants respectively.

Table 1. Average feed-in tariff rates applied in Latvia in 2012 [13]

\begin{tabular}{ll}
\hline Technology & Feed-in tariff, $€ \mathrm{c} . / \mathrm{kWh}$ \\
\hline Biogas & 19.5 \\
Biomass & 18.5 \\
Small hydropower $(<10 \mathrm{MW})$ & 18.1 \\
CHPs (<=4 MW) & 14.5 \\
CHPs (>4 MW) & 11.1 \\
Wind & 10.7 \\
\hline
\end{tabular}

Alternatively to feed-in tariff support mechanism, operators generating electricity in biomass and biogas power plants with installed capacity exceeding $1 \mathrm{MW}$ may qualify for rights to receive a guaranteed payment for the electric capacity installed in a power plant. The same term is applied to cogeneration power plants with installed electric capacity exceeding $20 \mathrm{MW}$. In addition to feed-in tariffs, grants for renewable energy projects in all sectors are provided by the national Climate Change Financial Instrument (managed by the Ministry of Environmental Protection and Regional Development) and European Union Structural Funds and the Cohesion Fund. Support intensity is in range 40-50\% of project's expenditure.

Despite the fact that feed-in tariffs have helped to develop the renewable electricity sector in Latvia, the support scheme for new installations was discontinued in 2011. This was result of increasing concerns about corruption, lack of transparency of the support system, and growing financial burden on electricity consumers. The Ministry of Economics of Latvia is currently working on the assessment and revision of the renewable electricity support scheme. Meanwhile the existing support scheme is on hold until 1 January 2016.

\subsubsection{Lithuania}

The structure of Lithuanian power generation changed significantly after the disconnection of the second reactor at the Ignalina nuclear power plant in 2010 which accounted for $80 \%$ of national power production. From energy exporting country Lithuania has become the most dependent EU Member State on electricity supply from abroad. Lithuania's national target is to reach $23 \%$ of renewables in final energy consumption ( $21 \%$ in the electricity sector) by 2020 compared to around $17 \%$ now [14]. Currently natural gas dominates in the electricity mix of Lithuania with a 55\% share. From renewable energy sources hydropower plays the major role as shown in Figure 2. Meanwhile solar electricity has started to develop only recently having installed $8 \mathrm{MW}$ by the end of 2012 . 


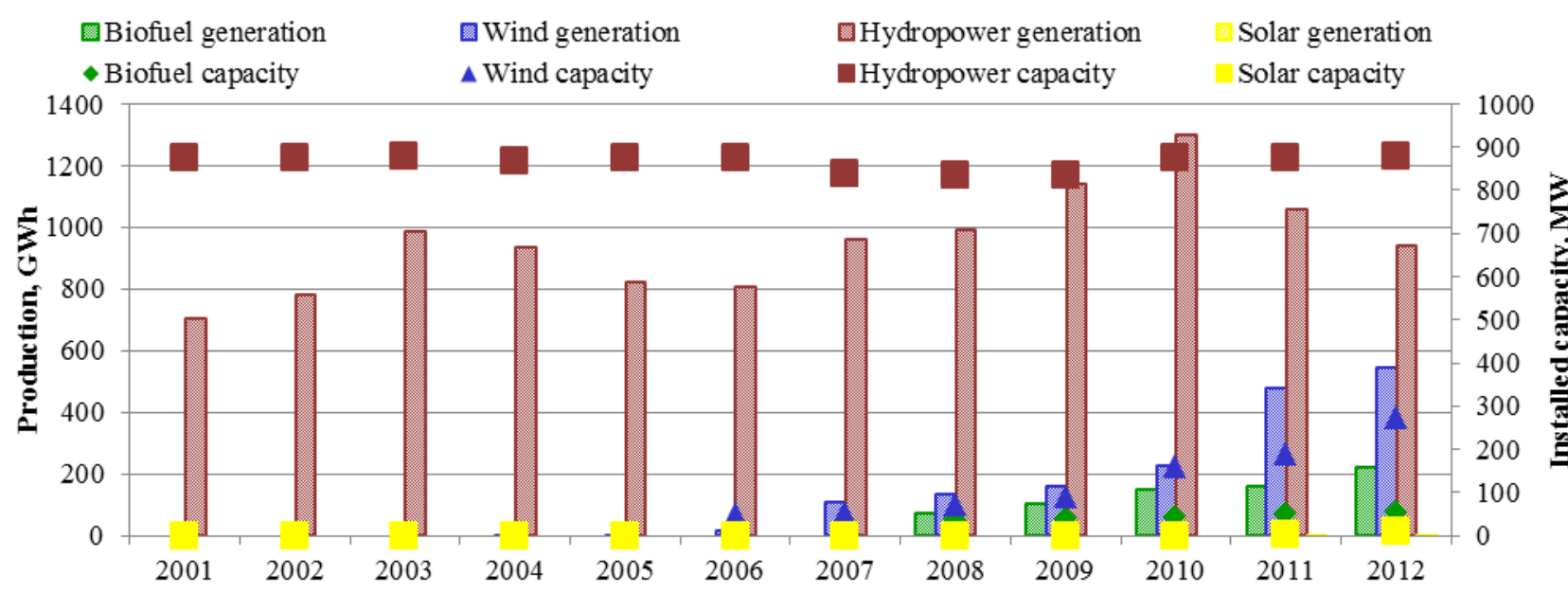

Fig. 2. Renewable electricity in Lithuania (Data source: [15])

In Lithuania, combination of three policy initiatives is applied to promote electricity generation from renewable energy sources, feed-in tariffs, grants, and tax regulation respectively.

Feed-in tariffs for renewable energy plants with a capacity exceeding $10 \mathrm{~kW}$ are awarded in tenders. The National Control Commission for Prices and Energy (NCC) quarterly sets the maximum feed-in tariff for the subsequent tender procedures and the tender is won by the participant offering the lowest feed-in tariff. Renewable electricity generated in plants with installed capacity less than $10 \mathrm{~kW}$ is purchased at a guaranteed price set by the NCC (payment applies to $50 \%$ of the electricity generated from RES during a calendar year). The feed-in tariffs are applied for the small-scale HPP (capacity less than $10 \mathrm{MW}$ ), wind power and biomass plants, as well as solar energy. Following feed-in tariff rates are applied in Lithuania [16]. Hydropower plants up to $10 \mathrm{MW}: 7.4 \mathrm{€c} / \mathrm{kWh}$; wind power plants: $8.6 € \mathrm{c} / \mathrm{kWh}$; biomass power plants: $8.6 € \mathrm{c} / \mathrm{kWh}$; solar PVs up to $100 \mathrm{~kW}: 46.5 € \mathrm{c} / \mathrm{kWh}$; solar PVs in rage $100 \mathrm{~kW}-1 \mathrm{MW}: 44.5 € \mathrm{c} / \mathrm{kWh}$, and solar PVs over $1 \mathrm{MW}: 43.1 € \mathrm{c} / \mathrm{kWh}$. Feed-in tariff support scheme was started to be applied in Lithuania from 1 April 2002, and will be managed until 31 December 2020.

Furthermore, the producers of renewable electricity may apply for grants from the Lithuanian Environmental Investment Fund and the Fund for the Special Programme for Climate Change Mitigation. Maximum subsidy intensity makes up to $80 \%$ of the total project expenses. Certain environmental criteria must be met by the project to receive full financing. Electricity production in wind power plants, as well as production of biogas is supported under the Rural Development Programme of Lithuania.

Besides the subsidies, the Fund of the Special Programme for Climate Change Mitigation grants loans for renewable energy projects. All loans granted shall be financed partly from the programme's budget and partly from the funds of a credit institution (minimum 20\% of the loan). The loan is paid out by a credit institution on behalf of the Ministry of Environment. All technologies used for renewable electricity generation are eligible for this scheme. Small scale (up to $250 \mathrm{~kW}$ ) biofuel, wind and solar installations are applicable for investment support under EU Structural Funds.

In addition, Lithuanian Law on Excise Taxes provides exemption from excise tax for electricity generated from renewable energy sources. Operators of biofuel plants also benefit from environmental pollution tax relief in respect of pollutants emitted into the atmosphere from stationary pollution sources.

\subsubsection{Estonia}

The main resource for electricity generation in Estonia is the local oil shale and its products (shale oil and oil shale gas) which accounts for $88 \%$ of national power production. Thus, Estonia is almost fully independent from the import of fuel upon the production of electricity.

Electricity production in Estonia amounted to $11,966 \mathrm{GWh}$ in 2012, of which $12.3 \%$ were produced from renewable energy sources (hydropower, wind, and biomass). Taking into account the extensive environmental impact of oil shale-fired power plants, the government of Estonia is drawing attention to necessity to increase the use of renewable energy sources in the electricity sector [17]. Much emphasis in this context is placed on the development of wind energy and biomass CHPs. One of the targets is to ensure that $20 \%$ of the gross electricity consumption in produced in cogeneration plants by 2020 . [18]. The deployment of RES-E generation in Estonia up to 2012 is illustrated in Figure 3. 


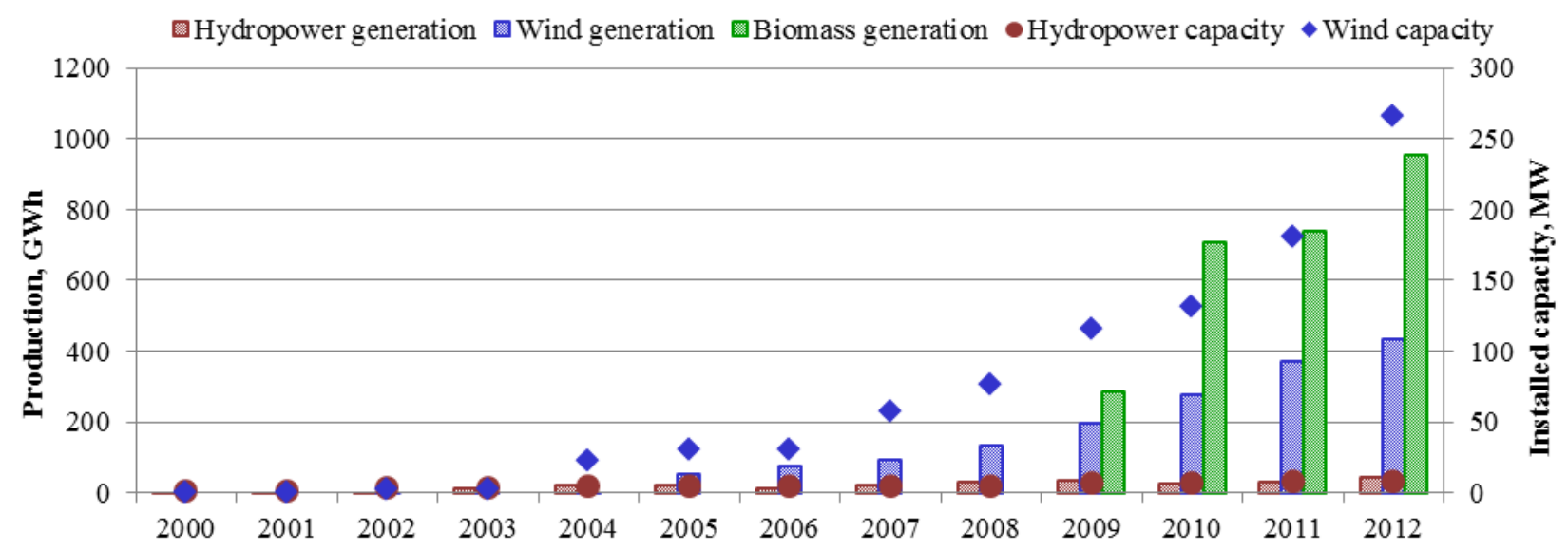

Fig. 3. Renewable electricity in Estonia (Data source: [19])

In Estonia, electricity generation from renewable energy sources is promoted through a premium tariff. The bonus payment on top of the electricity market price amounts to $5.4 € \mathrm{c} / \mathrm{kWh}$ and does not differ for the individual technologies. However, CHP plants with a production capacity below $10 \mathrm{MW}$ using waste, peat or oil-shale retorting gas are eligible for a tariff amounting to $3.2 € \mathrm{c} / \mathrm{kWh}$.

Investment support is available for bioenergy and wind energy installations, as well construction of CHP plants and infrastructure related to it (up to $60 \%$ of the eligible investment costs). In addition, $R \& D$ measures are implemented under the National Technology programme and the Development Plan for Enhancing the Use of Biomass and Bioenergy for the Period 2007 to 2030.

\section{Modelling the Baltic power sector}

\subsection{System dynamics}

System dynamics is a computer-aided modelling approach to policy analysis and design. System dynamics was developed in 1950s by professor Jay Write Forrester and is applied to dynamic problems arising in complex social, managerial, economic, or ecological systems [20]. The approach utilizes various control factors such as feedback loops and time delays to observe how the system reacts and behaves to trends [21]. System dynamics has been used to analyze energy issues since the 1970s, when large models were developed to increase the general understanding of energy policy [22]. A comprehensive literature review of system dynamics applications in the past is given in [23-24]. More recently system dynamics has been applied to analyze energy consumption and carbon emissions in industry [25-26] and in specific areas such as urban territories [27], world heritage areas [28], and industrial regions [29]. Blumberga et al. [30] and Kunsch \& Springael [31] have used system dynamics to analyze energy efficiency and $\mathrm{CO}_{2}$ emission reduction policies in the residential sector, while $[5,32]$ have analyzed possibilities for solar PV deployment. In electricity sector, system dynamics models have been developed to analyze options for $\mathrm{CO}_{2}$ mitigation [33] and renewable energy integration [21], and to electricity generation planning as described in [34-35].

\subsection{Model description}

Key stocks and flows of the proposed system dynamics model are presented in Figure 4. It shows the underlying connections between elements of the studied system. Installed capacity stocks (MW) with corresponding investment inflows and depreciation out-flows form the base structure of the model. For the sake of simplicity only two resource flows, renewable and fossil energy respectively, are shown. However, the real model consists of several resource flows corresponding to national electricity generation mix in Latvia, Lithuania and Estonia.

Investment decisions are fundamentally based on total revenues gained by investors [34] and electricity price is an important factor determining the willingness to invest in new electricity generation capacity [36]. Therefore it is assumed that investment decision among all provided technologies is done based on electricity generation costs. The average cost of electricity production is determined by four components: 1) technology investment costs, including planning and site work; 2) operation and maintenance (O\&M) costs; 3 ) fuel cost, and; 4) relevant premium, e.g. cost of $\mathrm{CO}_{2}$ emissions (negative) or state support incentives (positive). This is an equilibrium model thus the larger the investment share of one technology (e.g., renewable-energy-based), the smaller share of all investments reaches the other technology (e.g., fossil-fuel-based). Total annual investments in terms of MW per year are equal to total annual depreciation which is affected by technology lifetime. Annual electricity generation from each mode of resource is determined taking into account the installed capacity and technology specific full load hours. The exact values are determined the capacity factor multiplied by 8,760 hours. 


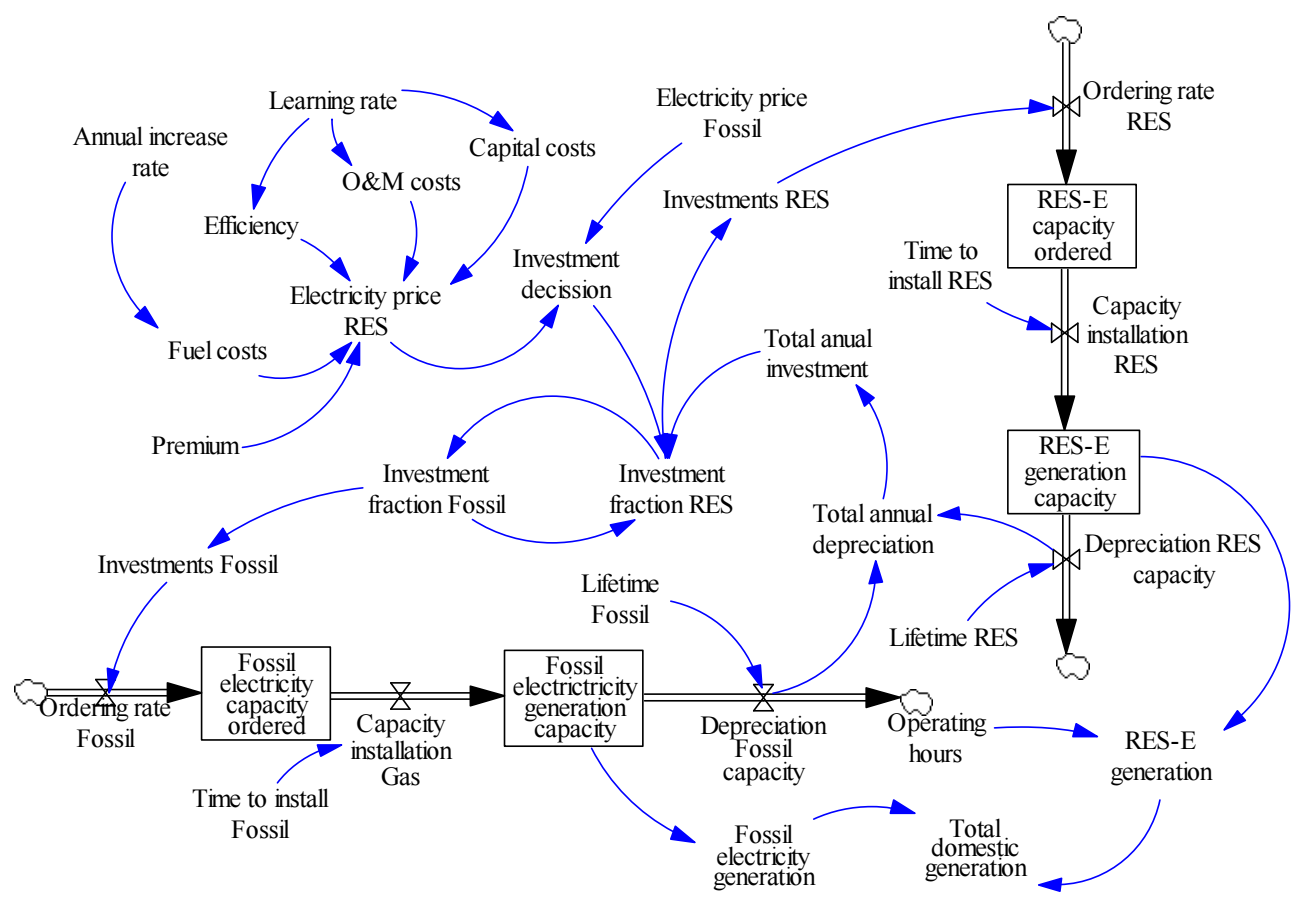

Fig. 4. Key stocks and flows of the system dynamics model

Based on previously described structure a system dynamics model representing electricity generation and demand till 2020 was developed and applied to conditions specific for each Baltic State. Powersim Studio 8 modelling software was used for model building. Aim of the model is to assess the performance of renewable electricity support instruments in promoting renewable electricity capacity development in the Baltic States.

\subsection{Scenario assumptions}

Table 2 summarizes findings on policy measures for support of electricity generation from renewable energy sources applied in the Baltic States. From Table 2 one can see that subsidies and feed-in tariffs (including premium tariff in Estonia) are the most widely applied policy instruments to promote the use of renewable energy sources in power generation. For further analysis in this study only feed-in/premium tariff instrument is chosen. Feed-in tariff rates included in the model are presented in Table 3.

Table 2. Renewable electricity support policies

\begin{tabular}{lccccc}
\hline Country & Subsidy & Loan & Feed-in tariff & Premium tariff & Tax regulation \\
\hline Estonia & $\checkmark$ & & & $\checkmark$ & \\
Latvia & $\checkmark$ & & $\checkmark$ & & $\checkmark$ \\
Lithuania & $\checkmark$ & $\checkmark$ & $\checkmark$ & & $\checkmark$ \\
\hline
\end{tabular}

Table 3. Feed-in/premium* tariff rates used in modelling, $€ \mathrm{c} / \mathrm{kWh}$

\begin{tabular}{lllllll}
\hline Country & Wind & Biomass & Biogas & Bioenergy & Solar & Natural gas \\
\hline Estonia & 5.0 & 5.0 & 5.0 & 5.0 & 5.0 & 5.0 \\
Latvia & 10.5 & 18.5 & 19.5 & - & 42.6 & 14.5 \\
Lithuania & 8.6 & - & - & 8.6 & 45.0 & - \\
\hline
\end{tabular}

* Estonia

Following resource flows corresponding to historical use pattern and projected future development were chosen in each of the Baltic States:

- Latvia: onshore and offshore wind power, electricity generation from biomass and biogas. Fossil fuel resource flow is represented by natural gas CHPs.

- Lithuania: onshore wind power, biofuel, and solar energy. Fossil fuel resource flow is represented by natural gas CHPs.

- Estonia: onshore and offshore wind power and electricity generation from biomass. Fossil fuel resource flow is represented by oil shale power plants. 
The main interest of this research is to look for possibilities of increasing the share of renewable energy sources, therefore development of nuclear power in Lithuania or any other of the Baltic countries is not considered. In addition to the above mentioned renewable energy sources, it is assumed that hydropower production remains at current level in Latvia and Lithuania, but no new investments for increasing the installed hydropower capacity are done.

\section{Results and discussion}

Modelling results are illustrated in Figure 5. It shows the projected deployment of installed capacity of renewable electricity production facilities in Estonia, Latvia, and Lithuania till 2020. Results are further compared with installed capacity development forecasts outlined in national renewable energy action plans.

In Latvia, the model shows inability of existing policy to reach national targets for almost all RES-E technologies except biogas. Following results for installed RES-E capacities by 2020 were obtained: onshore wind $140 \mathrm{MW}$ (236 MW projected); offshore wind $34 \mathrm{MW}$ (180 MW projected); biomass $50 \mathrm{MW}$ (108 MW projected); solar $0 \mathrm{MW}$ (4 MW projected), and biogas $150 \mathrm{MW}$ (92 MW projected). In order to follow projected RES-E development pattern and achieve targets outlined in the national renewable energy action plan, changes in feed-in tariff rates should be made. Following feedin tariffs are suggested: onshore wind $11.0 € \mathrm{c} / \mathrm{kWh}$; offshore wind $12.5 € \mathrm{c} / \mathrm{kWh}$; biomass $19.0 € \mathrm{c} / \mathrm{kWh}$ and biogas $19.3 € \mathrm{c} / \mathrm{kWh}$.

Model forecast for Lithuania: onshore wind $570 \mathrm{MW}$ (500 MW projected); bioenergy $74 \mathrm{MW}$ (224 MW projected), and solar power $15 \mathrm{MW}$ (10 MW projected). In order to promote power production from domestic bioenergy resources, feed-in tariff rate should be increased to $10.5 \mathrm{€c} / \mathrm{kWh}$. Model forecasts for Estonia: onshore wind $520 \mathrm{MW}$ (400 MW projected); offshore wind $80 \mathrm{MW}$ (250 MW projected), and biomass $87 \mathrm{MW}$ (no projections in the national renewable energy action plan). In order to follow projected RES-E development pattern, following premium tariff rates are suggested: onshore wind $5.1 € \mathrm{c} / \mathrm{kWh}$ and offshore wind $6.0 € \mathrm{c} / \mathrm{kWh}$.

A comparison of existing and proposed feed-in tariff rates in Latvia, Lithuania and Estonia is presented in Figure 6.

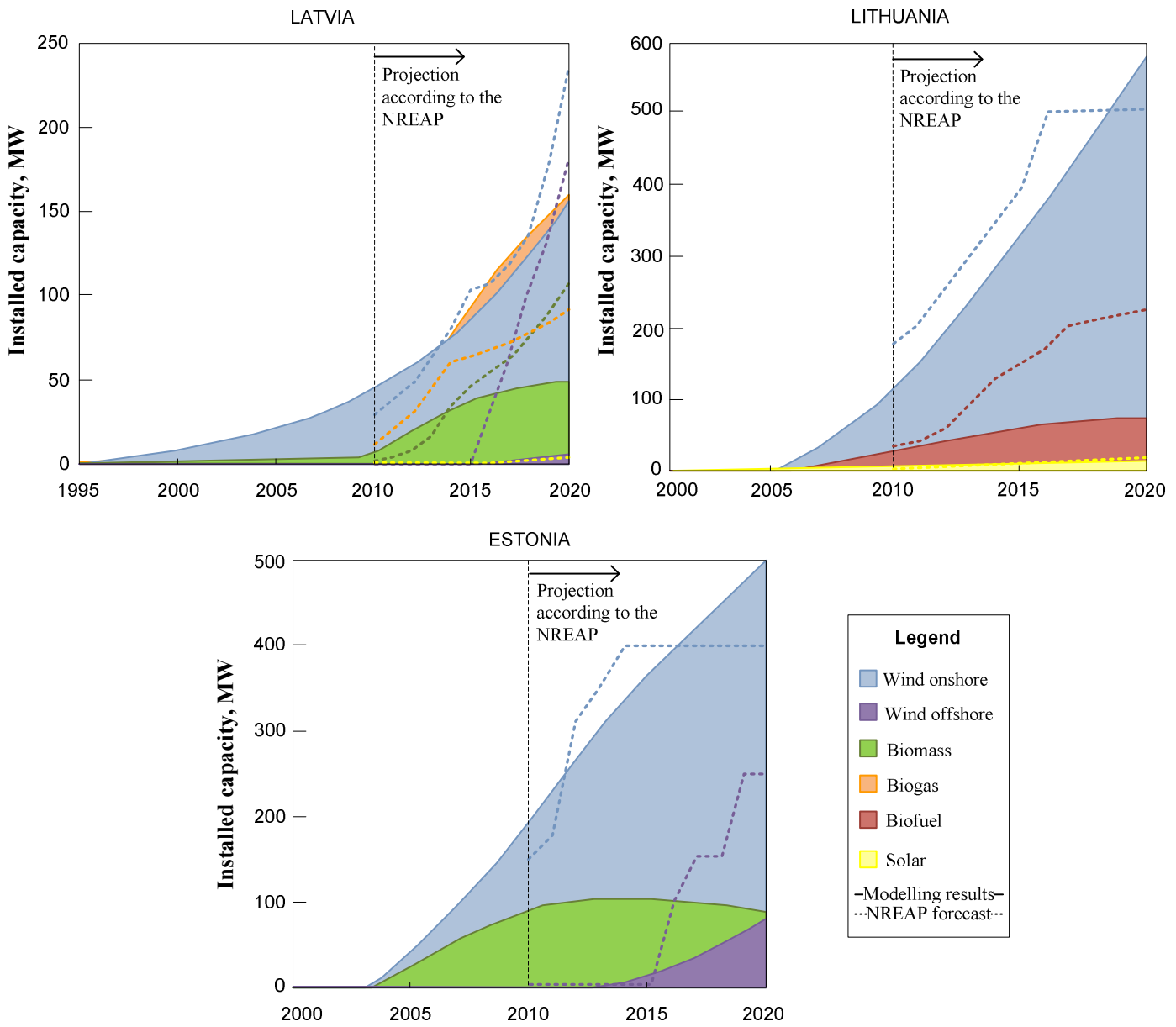

Fig. 5. Installed RES-E capacity in the Baltic States: Comparison of modelling results and NREAP forecasts 


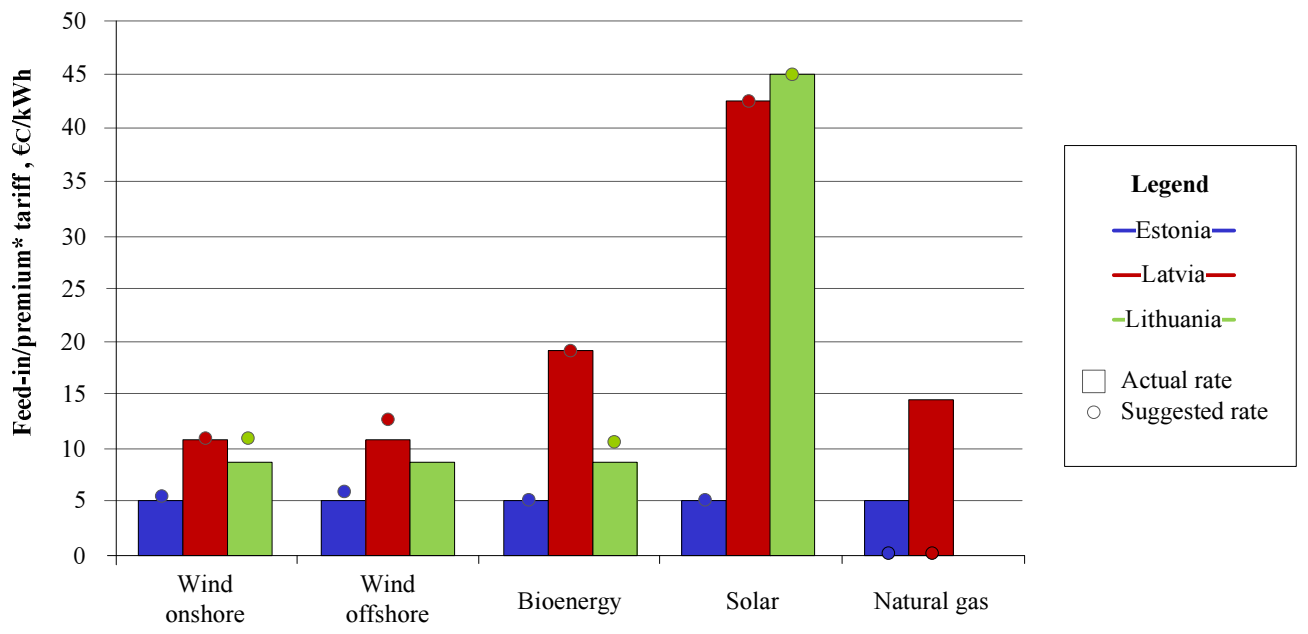

Fig. 6. Modelling results: Suggested feed-in tariff rates

\section{Conclusions}

This study has presented results of a dynamic model aimed to evaluate renewable power deployment in Latvia, Lithuania and Estonia until 2020. A system dynamics modelling approach was applied to simulate the future development of electricity sectors in Baltic States based on electricity cost analysis.

Feed-in tariff is the main policy mechanism to support renewable electricity generation the Baltic States. Modelling results affirm the ability of feed-in tariffs to increase installed RES-E capacity. However, adjustment of feed-in tariff rates is suggested in order to reach national renewable electricity targets.

\section{Acknowledgements}

This work was supported by Nordic Energy Research NORSTRAT project.

\section{References}

[1] European Commission. 2010. Communication from the Commission Europe 2020 A strategy for smart, sustainable and inclusive growth. COM (2010) 2020 final.

[2] Verbruggen, A.; Lauber, V. 2012. Assessing the performance of renewable electricity support instruments, Energy Policy 45: 635-644. http://dx.doi.org/10.1016/j.enpol.2012.03.014

[3] Mousavi, S.; Ghanbarabadi, M.; Moghadam, N. 2012. The competitiveness of wind power compared to existing methods of electricity generation in Iran, Energy Policy 42: 651-656. http://dx.doi.org/10.1016/j.enpol.2011.12.038

[4] Fagiani, R.; Richstein, J. C.; Hakvoort R.; De Vries, L. 2014. The dynamic impact of carbon reduction and renewable support policies, Utilities Policy 28: 28-41. http://dx.doi.org/10.1016/j.jup.2013.11.004

[5] Hsu, Ch. 2012. Using a system dynamics model to assess the effects of capital subsidies and feed-in tariffs on solar PV installations, Applied Energy 100: 205-217. http://dx.doi.org/10.1016/j.apenergy.2012.02.039

[6] Fouquet, D. 2013. Policy instruments for renewable energy - From a European perspective, Renewable Energy 49: 15-18. http://dx.doi.org/10.1016/j.renene.2012.01.075

[7] Del Rio, P.; Cerda, E. 2014. The policy implications of the different interpretations of the cost-effectiveness of renewable electricity support, Energy Policy 64: 364-372. http://dx.doi.org/10.1016/j.enpol.2013.08.096

[8] Jenner, S.; Groba, F.; Indvik, J. 2013. Assessing the strength and effectiveness of renewable electricity feed-in tariffs in European Union countries, Energy Policy 52: 385-401. http://dx.doi.org/10.1016/j.enpol.2012.09.046

[9] Central Statistical Bureau of Latvia [online]. 2014. Online energy data base [cited 1st January 2014]. Available from Internet: http://data.csb.gov.lv/Menu.aspx?selection=vide $\backslash I k g a d \% C 4 \% 93 j i e+$ statistikas+datilEner\%C4\%A3\%C4\%93tika\&tablelist=true\&px_language=en\&px type=PX\&px_db=vide\&rxid=cdcb978c-22b0-416a-aacc-aa650d3e2ce0.

[10] Ministry of Economics of Republic of Latvia. 2013. Latvian energy in figures, $43 \mathrm{p}$.

[11] Ministry of Economics of Republic of Latvia. 2010. Information Report: Republic of Latvia National Renewable Energy Action Plan for implementing Directive 2009/28/EC of the European Parliament and of the Council of 23 April 2009 on the promotion of the use of energy from renewable sources and amending and subsequently repealing Directives 2001/77/EC and 2003/30/EC by 2020, 103 p.

[12] Ministry of Economics of Republic of Latvia. 2013. Latvian energy long term strategy 2050 - Competitive energy for society, 14 p.

[13] Latvenergo [online]. 2013. Subsīdiju sadalījums elektroenerğijas ražošanai Latvijā [Subsidies for electricity generation in Latvia] [cited 21st January 2014]. Available from Internet:

http://www.latvenergo.lv/lat/oik/obligata_iepirkuma_komponente/subsidiju_sadalijums_elektroenergijas_razosanai_latvija/.

[14] Ministry of Energy of the Republic of Lithuania. 2012. National Energy Independence Strategy, $59 \mathrm{p}$.

[15] Lietuvos energetikos institutas. 2013. Lietuvos energetika 2012, 20 p.

[16] Ministry of Energy of the Republic of Lithuania. 2010. National Renewable Energy Action Plan of Lithuania, $135 \mathrm{p}$.

[17] Ministry of Economic Affairs and Communications of the Republic of Estonia. 2008. Development Plan of the Estonian Electricity Sector until 2018, $57 \mathrm{p}$. 
[18] Ministry of Economic Affairs and Communications of the Republic of Estonia. 2010. National Renewable Energy Action Plan of Estonia, 63 $\mathrm{p}$

[19] Statistics Estonia [online]. 2014. Annual energy statistics [cited 9 January 2014]. Available from Internet: http://pub.stat.ee/pxweb.2001/I_Databas/Economy/07Energy/02Energy_consumption_and_production/01Annual_statistics/01Annual_statistics.asp

[20] Blumberga, A.; Blumberga, D.; Bazbauers, G.; Davidsen, P.; Moxnes, E.; Dzene, I.; Barisa, A.; Zogla, G.; Dace, E.; Berzina, A. 2011. System dynamics for environmental engineering students. Riga: Riga Technical University Institute of Energy Systems and Environment, $351 \mathrm{p}$

[21] Aslani, A.; Helo, P.; Naaranoja, M. 2014. Role of renewable energy policies in energy dependency in Finland: System dynamics approach, Applied Energy 113: 758-765. http://dx.doi.org/10.1016/j.apenergy.2013.08.015

[22] Ochoa, P.; Van Ackere, A. 2009. Policy challenges and the dynamics of capacity expansion in the Swiss electricity market, Energy Policy 37: 19831998. http://dx.doi.org/10.1016/j.enpol.2009.01.044

[23] Kilanc, G. P.; Or, I. 2008. A decision support tool for the analysis of pricing, investment and regulatory processes in a decentralized electricity market, Energy Policy 36: 3036-3044. http://dx.doi.org/10.1016/j.enpol.2008.03.034

[24] Hasani, M.; Hosseini, S. H. 2011. Dynamic assessment of capacity investment in electricity market considering complementary capacity mechanisms, Energy 36(1): 277-293. http://dx.doi.org/10.1016/j.energy.2010.10.041

[25] Ansari, N.; Seifi, A. 2013. A system dynamics model for analyzing energy consumption and $\mathrm{CO}_{2}$ emission in Iranian cement industry under various policy and export scenarios, Energy Policy 58: 75-89. http://dx.doi.org/10.1016/j.enpol.2013.02.042

[26] Mao, G.; Dai, X.; Wang, Y.; Guo, J.; Cheng, X.; Fang, D.; Song, X.; He, Y.; Zhao, P. 2013. Reducing carbon emissions in China: Industrial structural upgrade based on system dynamics, Energy Strategy Reviews 2(2): 199-204. http://dx.doi.org/10.1016/j.esr.2013.07.004

[27] Feng, Y. Y.; Chen, S. Q.; Zhang, L. X. 2013. System dynamics modelling for urban energy consumption and $\mathrm{CO}_{2}$ emissions: A case study of Beijing, China, Ecological Modelling 252: 44-52. http://dx.doi.org/10.1016/j.ecolmodel.2012.09.008

[28] Wu, Z; Xu, J. 2013. Predicting and optimization of energy consumption using system dynamics - fuzzy multiple objective programming in world heritage areas, Energy 49: 19-31. http://dx.doi.org/10.1016/j.energy.2012.10.030

[29] Li, F.; Dong, S.; Li, Z.; Li, Y.; Li, S.; Wan, Y. 2012. The improvement of $\mathrm{CO}_{2}$ emission reduction policies based on system dynamics method in traditional industrial region with large $\mathrm{CO}_{2}$ emission, Energy Policy 51: 683-695. http://dx.doi.org/10.1016/j.enpol.2012.09.014

[30] Blumberga, A.; Blumberga, D.; Bazbauers, G.; Zogla, G.; Laicane, I. 2014. Sustainable development modelling for the energy sector, Journal of Cleaner Production 63: 134-142. http://dx.doi.org/10.1016/j.jclepro.2013.05.020

[31] Kunsch, P.; Springael, J. 2008. Simulation with system dynamics and fuzzy reasoning of a tax policy to reduce $\mathrm{CO}_{2}$ emission in the residential sector, European Journal of Operational Research 185(3): 1285-1299. http://dx.doi.org/10.1016/j.ejor.2006.05.048

[32] Movilla, S.; Miguel, L. J.; Blazquez, L. F. 2013. A system dynamics approach to the photovoltaic energy market in Spain, Energy Policy 60: 142-154. http://dx.doi.org/10.1016/j.enpol.2013.04.072

[33] Saysel, A.; Hekimoglu, M. 2013. Exploring the options for carbon dioxide in Turkish electric power industry: System dynamics approach, Energy Policy 60: 675-686. http://dx.doi.org/10.1016/j.enpol.2013.04.053

[34] Pereira, A. J. C.; Saraiva, J. T. 2013. A long term generation expansion planning model using system dynamics - Case study using data from the Portuguese/Spanish generation system, Electric Power Systems Research 97: 41-50. http://dx.doi.org/10.1016/j.epsr.2012.12.001

[35] Qudrat-Ullah, H. 2013. Understanding the dynamics of electricity generation capacity in Canada: A system dynamics approach, Energy 59: 285-294. http://dx.doi.org/10.1016/j.energy.2013.07.029

[36] Nielsen, S.; Sorknæs, P.; Ostergaard, P.A. 2011. Electricity market auction settings in a future Danish electricity system with a high penetration of renewable energy sources - A comparison of marginal pricing and pay-as-bid, Energy 36: 4434-4444. http://dx.doi.org/10.1016/j.energy.2011.03.079 